\title{
Re-Inventing Traditional Textiles For The Contemporary Design Culture
}

Traditional textiles have played a crucial role in creating awareness as cultural heritage and building a cultural identity and sustainability in contemporary design culture in Turkey. However, traditional textile weaving is threatened with extinction due to the need for specialist skills involved in hand weaving, the rapid growth of industrial production is facing with the treat of extinction.

This study aims to focus on the regional development of traditional textiles, which is a potential source of support for local economies, thus contributing to increase the value of the material, and emphasizing cultural identity. In this respect, local silk textile production in Ödemiş, Birgi villages in İzmir, and the use of silk fabrics as ethnical sources for design inspiration will be analyzed as a representative of the collective memory of Turkish design culture. Correspondingly, two well-known Turkish designers, Zühal Yorgancıoğlu and Esin YIlmaz, works will be analyzed through interpretation of their design works. This analysis will be based on the concepts of local and cultural identity, authenticity, sustainability, collective memory and intergenerational equity in terms of interaction of traditional textiles with contemporary design culture.

keywords traditional textiles, cultural identity, collective memory, material culture, intergenerational equity

\section{Introduction}

Due to sustainable and ecological awareness in contemporary design culture, there is a renewed interest in traditional textiles in the contemporary fashion world; owing to rarity of availability of these materials by designers, they currently play a very minor role in design culture. However, with respect to traditional textiles' design and business potential, these materials contribute to a region's local identity in the context of crafts value, production of collective memory, social responsibility, intergenerational equity, and sustainability, as well as contributing to the local economy.

Ezio Manzini refers the role of traditional materials in making use of local knowledge, value and experience, thus creating a design process that is socially responsive, and connected to a local system, such a process provides locals with a source of income, and allows knowledge to be translated into valorized and well-crafted products (Manzini, 2010:10).

Hazel Clark gives the example of Brazilian case which the worldwide designers such as Rosa Cha, Carlos Miele and Campana Brothers, have become notable through their "Latin" style. This style involves local culture in the form of women's collections from favalas, in the production process. Through this system, the design industry has made an important 
contribution to Brazilian economy, while promoting the concepts of a "multi-local" society and a "distributed economy" (Clark 2008: 430). Such a design production, not only fosters social innovation and solidarity, but also acts as a stimulus activating social and collective memory (Kipöz, 2013).

In the Turkish textile culture, the regional value of the traditional silk textiles, considered to be a resource for the development and support for local economies, helps to reinforce the definition, of their cultural identity and their design process, as well as contributing to the production of collective memory. Instrumental in this process of developing identity in the Turkish clothing culture is silk production in the village of Ödemiş-Birgi, in the province of İmir, Turkey.

\section{Methodology}

The main focus of the study is regional development of textile culture in relation to contemporary design. In particular, the villages, Ödemiș and Birgi, where silk production had been carried out for centuries, are examined, as textiles produced here have been influential on certain Turkish designers within the region. In addition to this research, visual sources gathered during field trips to Ödemiș and Birgi are used to evaluate the impact of local textiles on contemporary design culture. This visual data is the outcome of the field study conducted with the regional local silk producers, weavers in Ödemiș in 20122013. Moreover, in depth interviews with the designers, along with their visual archive are used as primary resources. These works are analyzed within the context of authenticity, sustainability, social role and intergenerational relations in contemporary design culture.

\section{Re-inventing Identity with Traditional Textiles and the Use of Ödemiş Silk Textiles in Contemporary Fashion Design}

Since the 1300s, silk production has played an important role in the cultural and institutional life of Anatolia and the Ottoman Empire. Local production, based on silkworm production and hand woven textiles developed mainly in the Ödemiş-Birgi region (Önlü, 2013: 47-60). Silk production in Ödemiş, being an important employment for local workers, thus created a local economy for the region. Considering their skillful hand weave production techniques, which requires experience and patience, each piece of the silk fabric is a unique creation. Correspondingly, rarity of the material, along with the scarcity of production fields, adds value to silk materials.

In Turkey, 1970s saw the emergence of the fashion industry, which led to the development of ready-to-wear culture, under the influence of the youth movements and democratization. Due to demographical transformation of cities into a more heterogeneous culture, local and global values began to interact with the new consumption patterns. This caused an interest in using local materials in contemporary design. This point of the study will analyze the design approaches and methods of two designers who were pioneers in the revival of local and cultural identity in fashion design, particularly of the resources from Ödemiş-Birgi. These are Zühal Yorgancıoğlu and Esin Yılmaz, respectively from the first and second generation designers living and working in İmir.

Zühal Yorgancıoğlu (1924-) adopt two different identities in her contemporary designs; Anatolian and Ottoman. The two common features of her designs are the use of Turkish motifs as embroideries, which create graphical patterns over the body, and the use of traditional and local textiles. 

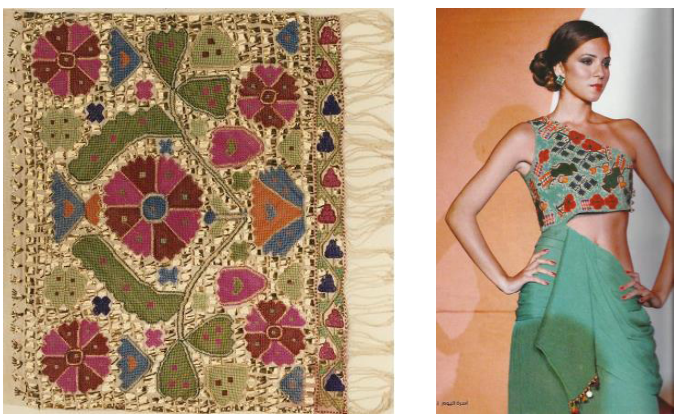

Figure 1 (left),

Detail of a silk

embroidery;

Figure 2 (right). Silk dress by Zühal Yorgancıoğlu.

Yorgancıoğlu's design library consists of items from Turkish clothing culture such as inner robes, kaftans', șalvars ${ }^{2}$, cepkens ${ }^{3}$, tunics, shirts made of bürümcük fabrics ${ }^{4}$, dresses which have been re-invented and re-interpreted in accordance with a contemporary design language. Bürümcük shirts are mostly woven with raw cotton and silk fibers and constitute an important part of the Ödemiş local textile culture. In her Anatolian collection, there are silk bürümcük fabrics, hand-woven textiles which reflect the diversity of Anatolian colors, embroideries and patterns produced by special techniques, called Taşköprü and Tel kırma.

Similarly, Esin Yllmaz (1944-2011), her inspirations from local resources, mythological stories, legends and folkloric influences from Anatolia, and them into contemporary fashion language. In her designs, social responsibility and cultural sensitivity are clearly visible, highlighting her awareness of disappearance of local and natural sources. She used needleworks, hand-woven bürümcük silk fabrics along with golden and silver Tel kırma embroideries. The structure of her designs was created with a respect for authentic materials, with an attempt to drape the fabric flow around the body as naturally as possible. Also needlework was used to frame the entire dress, emphasizing her indebtedness to local and cultural narratives. Most of her designs were experimental, with inspiration taken from traditional Anatolian garments, and Hellenistic and Roman architecture from the Aegean region.

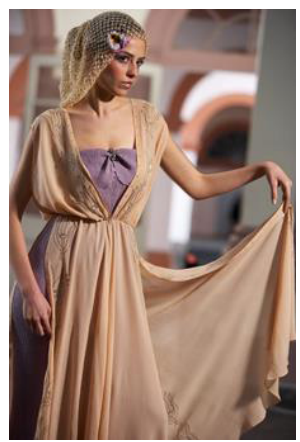

Figure 3.

Double layered outfit constructed by a strapless silk bürümcük dress and another silk crep tunic dress with Tel kırma embroidery technique, Photography: Emin Emrah Yerce.

\footnotetext{
${ }^{1}$ Kaftan is a long jacket used as outer wear (Author's note).

${ }^{2}$ ŞalvarisaloosebifurcatedtrouserusedinTurkishdressculture(Author'snote).

${ }^{3}$ Cepken is a short jacket used in Turkish dress culture ( Author's note).

${ }^{4}$ Name of a special Ödemiş silk fabric woven with twisted weft yarns to create a crinkle effect (Author's note).
} 


\section{Intergenerational Equity, Sustainability and Cultural Identity:}

As a response to decline in production of traditional textiles and hand crafts due to industrialization, efforts have been made to resurrect these authentic and cultural values in textiles. This involved the foundation of educational institutions to train modern women of the Turkish Republic to revive traditional textile production. Even though both Yorgancıoğlu and Yılmaz were graduates of these schools, they challenged the conventional approach of these schools, which simply aimed to reproduce historical examples of craftwork, rather than to re-interpret them and adapt them to contemporary design culture.

The designers also become actors for creating intergenerational equity, by transferring the traces of the local traditions to younger generations through their contemporary design approach. Especially in Yorgancıoğlu's design experience, this is achieved by transforming old and discarded ancient fabrics and embroideries into new designs, through the method of up-cycling design practice.

Their design journey in relation to a certain place, identity and belonging can be associated with the concept of cultural geography. This concept was introduced by anthropologist Carl Sauer to describe how cultural products and norms become instrumental in analyzing the ways language, religion, economy, government and other cultural phenomena vary or remain constant, from one place to another (Welters, Lillethun, 2011). In this respect, for cultural geographer Wibur Zelinsky, the cultural geography constructed by clothing refers to the spatiality of the material. The material oriented approach of both designers is formed by, and taken is value from this spatiality.

\section{Re-Invention of Tradition through Local Textiles}

The systematic use of Turkish motifs in clothing styles of Yorgancıoğlu can be considered more as a representation of culture, national identity and historical continuity, rather than mere creation of a style. This relates to the discovery of the re-construction of traditions which can be traced back to the culture of the Ottoman and Anatolia. According to Aasim Akhtar who interpreted her fashion show in Pakistan, one of the most prominent historians of our age, Eric Hobsbawm defines this situation as "invention of tradition". For him; "Invented tradition is a concept to mean a set of practices normally governed by overtly or tacitly accepted rules and of a ritual or symbolic nature, which seek to inculcate certain values and norms of behavior by repetition, which automatically implies continuity with the past. In fact, they normally attempt to establish continuity with a suitable historic past" (Hobsbawm, Ranger: 1992: 1)

Yorgancıoğlu's use of Turkish motifs and embroidery as a symbol of Turkishness, and their historical significance in Turkish textile culture is an indicator of her invention of tradition, in line with Hobsbawm's theory. In this context, she is a cultural missionary who prioritized tradition as an ideological symbol of the nation- state and cultural identity, rather than simply being a fashion designer with an ethnical style. This approach is possible due to her deep knowledge of textile production and crafts, which are essential to her design process.

Similarly in the case of Yılmaz, tradition again functions as a means of historical continuity, and as a sign of cultural identity. However, she follows a more experimental and conceptual route remaining completely faithful to the origin of authentic material and the cultural meaning of design elements in her understanding of tradition. 
In addition to the above mentioned concept of invention of tradition in order to understand the relation between traditional materials and contemporary design practice, Conti and Vacca introduce an analysis of possible types of innovation that can be applied to the material culture of local crafts. They propose three lines of reflection as; (re) projected tradition in which existing crafts techniques are adapted to different needs, re-projected and removed from their original context in order to generate new languages and new meanings according to contemporary needs; (re) interpreted tradition in which manual traditions are recovered by partially removing them from their context, while the productive know-how continues to have its roots in the local territory. This is done so that traditions can be adapted to different platforms. Lastly, (re) innovated tradition in which traditional processes remain strongly tied to their original territory, and innovation becomes a tool primarily for the local communities themselves.

Silk production takes its cultural and symbolic value from its production process, which is performed by expert craftsmen with inherited know-how from past generations, tacit knowledge gained through particular skills and artisanship. Correspondingly, this value is reflected in the end product, thus creating material-oriented contemporary designs. Thus, above mentioned $(\mathrm{Re})$ innovated tradition is in tune with the local production model of silk textiles, whereas (Re) interpreted tradition coincides with their integration with design culture, due to designer involvement in production.

\section{Conclusion}

As a locally produced resource, regional silk textile production created its own tradition, which spread over centuries, due to its reproducible, repeatable, static and conventional crafts value. On one hand it creates sustainable, intergenerational and cultural merits, on the other, produces local economies. The discovery of traditional silk textiles in the second half of the 2oth century by two Turkish fashion designers from different generations has created a new awareness of this heritage of craft production. These designers made use of Ödemiş silk textiles in their creations for a number of reasons; to resist global culture and mechanization brought by industrial production, to appropriate local values, cultural heritage and national identity in to contemporary design culture; and to sustain values and traditions inherited from past generations, which are in danger of disappearing.

Unfortunately, the work of these designers remains unfinished, and the narrative of re-interpretation and re-invention of tradition could not be transmitted to the younger generations. This is due to the limited nature of local silk production, and the fact that production, and the business model is based on the effects of individuals, rather than related institutions. However, such production retains its key role as part of a creative solution to current issues in fashion, as a sustainable and ethical fashion system, which contributes to the reproduction of collective memory, intergenerational equity and the preservation of cultural identity. These designers represented themselves through appropriating traditional silk textile production into contemporary design culture and thus, in the words of Hobsbawm, "re-invented the tradition". 


\section{References}

Clark, H. (2008). 'Slow+Fashion- an Oxymoron- or a Promise for the Future...?', Fashion Theory, vol. 12, issue.4, pp. 427-446.

Conti, G.M. \& Vacca F. (2008) 'Textile Traditions and Fashion Design: New Experiential Paths', [Electronic], Umberto Allemandi \& C, pp. 1-14, Available: http://www.allemandi. com/cp/ctc, [20 Jan 2014].

Hobsbawm E. J. and Ranger T. O. (1992) The Invention of Tradition, Cambridge University Press. Kipöz, Ș. (2013) 'Slow Fashion Ethics: Re-production of Memory through Deconstruction', 10th European Academy of Design Conference - Crafting the Future.

Manzini, E. (2010), 'Small, Local, Open, and Connected: Design for Social Innovation and Sustainability', The Journal of Design Strategies: Change Design, Vol.4, No.1, Spring 2010, pp. 8-11.

Önlü, N. (2013) 'Ege Bölgesi El Dokuma Kaynakları', [Electronic], Atatürk Üniversitesi Güzel Sanatlar Fakültesi Sanat Dergisi, Sayı 23, pp. 47-6o, Available: http://e- dergi.atauni.edu.tr/ index.php/gsfd/article/viewFile/5956/5742, [20 Jan 2014].

Welters L. (ed) and Lillethun A. (ed) (2007), The Fashion Reader, Berg. 